\title{
announcement
}

\section{Symposium on the history, theory and methodology of regional archaeological projects}

From Wednesday, January 17th, until Friday, January 19th 1996, the fifth Symposium on Archaeology and Theory will take place in Leiden (the Netherlands). The symposium series started in 1990 as an initiative of a small group of Dutch archaeologists to discuss theoretical approaches. In subsequent years, this first meeting has developed into an annual event which is attended by a large part of the Dutch archaeological community. At its yearly two-day meetings in January, recent theoretical perspectives (both in the Netherlands and abroad) are presented and discussed. Theoretical and cross-disciplinary debate has always been a central feature. In celebration of the 5th anniversary of this symposium in 1996, a three-day international (English- language) symposium will be organized in the same spirit on the theme of The history, theory and methodology of regional archaeological projects. Contributors from various countries and from different archaeological sub-disciplines have been invited to comment on several aspects of regional research. In order to promote debate, the conference has been divided into subsections each comprising two papers. These will be introduced by an internationally known scholar, who will also chair the ample period scheduled for discussion following the papers.

Regional archaeological projects have become a hallmark of Dutch archaeology. Despite differences in regions and periods covered, they blend a strong continental tradition of empirical research with approaches often inspired by processual archaeology. They include elaborate reconstructions of landscape genesis, systematic regional surveys and large-scale excavations of settlements and cemeteries. Research on successions of house and settlement types is combined with the regional analysis of social and political developments over relatively long periods of time. Similar projects can be found in other European countries such as Denmark, Germany and England. In the Mediterranean these projects have developed a distinctive character with an emphasis on field survey.

All these regional projects have changed considerably over the years. We can observe changes in central objectives and problems, in theoretical and methodological premises, in available techniques and empirical results. A critical assessment of these changes, particularly the interaction between empirical work and theoretical debate, constitute the subject of this symposium.

On the first day, the history of regional archaeological research in Europe and the interactions of theory, method and practice will be examined; the second day will focus on the role of landscape and the third day will regard matters of cultural identity and heritage. 


\section{Trends and traditions across Europe}

As an introduction to the symposium, trends and traditions of regional archaeological research in both north-western Europe and the Mediterranean will be reviewed. With the socioeconomic context as a point of reference, the experiences of some major projects in both areas will be discussed. The merits of the approaches in each area will be pointed out, allowing insight into divergencies and similarities in regional archaeology both north and south of the Alps, as well as offering a historical background for the entire symposium.

\section{Interactions of method, theory and practice}

Interactions of method, theory and practice represent a central concern of this symposium. Against the backdrop of general theoretical development in archaeology, four specific regional projects, representing a wide of range of theoretical orientations and geographical perspectives, will be presented. It will be examined how their theoretical and methodological perspectives developed in the course of the project and how such changes can be related to practical issues raised during fieldwork or to theoretical considerations in the wake of archaeological debate in general. All projects discussed offer illustrative examples of the entanglement of theory and practice in regional archaeological research.

\section{Archaeological approaches to landscape}

Landscape has long been an important object of study for regional projects and has accordingly been studied from a wide range of perspectives. The second day of the conference focuses on three distinct approaches to landscape and its role in human society which can be related to specific moments in the history of archaeological thought.

MAN AND ENVIRONMENT The relationship between man and his physical environment constitutes a fundamental issue in archaeology. The ways in which people made certain choices and avoided others when facing the possibilities and limitations of the physical environment have been studied from various perspectives. Regional archaeological projects enable longterm overviews of man-environment interactions. The two contributions to this subsection will specifically show how the data obtained by these projects may stimulate reflection on this important theme.

PERCEIVING LANDSCAPE Studying how people experience the landscape they live in has become a new and exciting development in landscape archaeology. This experience is argued to have a direct bearing on the way people deal with and physically organize their environment. Both papers of this subsection will illustrate how regional archaeological projects may gain insight into the immaterial dimensions of landscape by exploring the relationship between land use and landscape perceptions. 
NEW TOOLS FOR LANDSCAPE ANALYSIS New techniques are frequently welcomed as enabling significant advances in the study of landscapes. Do new techniques, however, also allow better interpretations? Regional archaeological projects have often employed sophisticated techniques, but their contribution to these projects have rarely been assessed. In this subsection, GIS and geographical approaches are the analytical tools under scrutiny. On the basis of two regional projects, it will be examined how such tools can contribute to the study of landscapes and how their application has been directed by theoretical views.

\section{Issues of cultural identity and heritage}

Cultural identity and heritage are issues which stem from the awareness that regional projects cannot be carried out in isolation: studying the archaeological record of a region inevitably bears on matters of heritage and cultural identity. Few regional projects, however, have explicitly addressed the latter issue, while the former is usually dealt with by separate (state) organizations. Nevertheless, notions of cultural identity and heritage sometimes heavily influence regional research. The third conference day will be dedicated to the question of how claims and perceptions of identity may influence the aims of regional projects and their ways of handling the archaeological record.

CULTURAL IDENTITY The role of regional projects in the construction of regional or even national(ist) identities has occasionally been acknowledged. Apart from certain obvious cases of explicit propaganda, how should archaeologists handle situations where their conclusions are embraced for other purposes? How are archaeologists working abroad influenced by their own ideas about the contemporary situation of the region they are working in? Both contributions to this subsection argue that issues of cultural identity bear archaeological relevance. The question is to what extent changing ideas about cultural identity have played a role in regional archaeological research.

CULTURAL HERITAGE The relevance of regional projects to cultural heritage is too evident to be ignored: both concrete data and resulting interpretations may significantly contribute to a more complete understanding of local experience as well as to the archaeological importance of a region. Yet, concrete contributions to the management of regional cultural heritage are hard to come by, as most regional projects are carried out in a different institutional context. 174 Papers in this subsection show how a regional project may contribute to a fuller understanding of regional cultural heritage and eventually to its preservation and management.

MALTA AND THE FUtURE The 1992 Malta Convention (shorthand for European Convention on the Protection of the Archaeological Heritage) is bound to have profound consequences for regional archaeological projects, both in terms of finance and research planning. While there can be little doubt as to its significance, there is less agreement about how to realize it in practice. Should heritage management throughout Europe be squeezed into a single straitjacket or should there be space for national differences? Two contributions will explore the 
consequences of the Malta Convention for regional projects in the Netherlands and France respectively, highlighting in particular the impact on existing traditions of archaeological research and heritage management.

Contributors to the conference include P. Attema, C. Bakels, G. Barker, B. Bender, A. Billamboz, J. Bintliff, R. Bradley, R. Brandt, B. Chapman, M. Edmonds, C. Evans, A. Flemming, H. Fokkens, M. Fotiades, H. Groenendijk, K. Kristiansen, K. Randsborg, M. Rowlands, N. Roymans, H. Schlichtherle, A. Sherratt, S. Stoddart, H. Stoepker, N. Terrenato, F. Theuws, D. van der Waals, M. Wansleeben

\section{Contact address}

5th Symposium on Archaeology and Theory

Archeologisch Centrum

Postbus 9515

2300 RA LEIDEN

The Netherlands

Fax: +31 71272429

E-mail: ats96@rulpre.LeidenUniv.nl

\section{Note}

The international fifth Symposium on Archaeology and Theory is organized by the Archaeological Dialogues Foundation, which publishes the journal of the same name, and the National Research School for Advanced Studies in Archaeology ARCHON.

The latter was recently founded by the main Dutch archaeological institutes with the support of the Netherlands Organization for Scientific Research (NWO). ARCHON is also the principal sponsor of the symposium. 